\title{
PENGARUH BELAJAR KELOMPOK PENDIDIKAN KEWARGANEGARAAN (PKn) TERHADAP MINAT BELAJAR SISWA KELAS X DI SMKS-PP PUTRA JAYA STABAT KABUPATEN LANGKAT TAHUN PELAJARAN 2020/2021
}

\author{
Sri Ulina Br. Ginting ${ }^{1}$, Muhlis Fahdiar Sembiring ${ }^{2}$, Agustinawati $^{3}$ \\ Mahasiswa STKIP Budidaya Binjai ${ }^{1}$, Dosen STKIP Budidaya Binjai ${ }^{2,3}$ \\ (e-mail : sriulina20191@gmail.com) $\left.\left.{ }^{1}\right),(\text { e-mail : muhlisfahdiars@gmail.com })^{2}\right)$ \\ (e-mail : watiagustina962@gmail.com $)^{3}$ )
}

\begin{abstract}
ABSTRAK
Tujuan penelitian adalah untuk mengetahui pengaruh belajar kelompok Pendidikan Kewarganegaraan (PKn) terhadap minat belajar siswa kelas X di SMKS- PP PUTRA JAYA STABAT Kabupaten Langkat Tahun Pelajaran 2020/2021. Metode penelitian ini adalah metode penelitian kuantitatif survey. Alat pengumpul data pada penelitian ini adalah observasi dan angket. Dari hasil penelitian diperoleh 25,6\% siswa menunjukan kategori persepsi positif dan 74,4\% menunjukan kategori persepsi sangat positif. Dengan rata-rata 87 dengan kategori persepsi sangat positif. Minat belajar siswa setelah pelaksanaan belajar kelompok menunjukan persepsi sangat positif yang artinya dengan belajar kelompok minat belajar siswa semakin tinggi. Berdasarkan pembahasan hasil penelitian menunjukan hipotesis yang diajukan terbukti kebenarannya yaitu tingginya minat belajar pendidikan kewarganegaraan (PKn) siswa setelah diterapkan belajar kelompok pada siswa kelas X SMKS-PP PUTRA JAYA STABAT tahun pelajaran 2020/2021.
\end{abstract}

Kata Kunci : Belajar Kelompok, Minat Belajar PKn 


\section{PENDAHULUAN}

Belajar dan mengajar adalah dua proses yang mempunyai hubungan yang sangat erat dalam dunia pengajaran. Biasanya pengajaran dikhususkan kepada siswa dan mengajar kepada guru, sekalipun keduanya, baik guru atau siswa dapat melakukan keduanya. Proses balajar dan mengajar merupakan kegiatan pokok yang harus diselesaikan. Demikian juga siswa yang mempunyai pengetahuan kemampuan dasar dalam topik yang akan diajarkan akan mudah bagi guru untuk menyampaikan proses kegiatan belajar mengajar.

Dalam kegiatan belajar mengajar digunakan cara bagaimana dapat menarik perhatian siswa agar mereka dapat senang dan antusias dalam menerima dan merespon pelajaran yang disampaikan oleh guru. Kegiatan yang dilakukan seperti membaca, demonstrasi, mencari jawaban terhadap soalsoal, membuat contoh-contoh serta mengklasifikasikan suatu objek. Dengan kata lain memberikan pembelajaran akan siswa terangsang untuk belajar.

Ada beberapa pengertian tentang belajar baik dilihat dalam arti luas ataupun terbatas khusus. Muhibbin (2010:90) "Belajar adalah tahapan perubahan seluruh tingkah laku individu yang relatif menetap sebagai hasil pengalaman dan interaksi dengan lingkungan yang melibatkan proses kognitif'. UU Sisdiknas No 20 Tahun 2003, "pada dasarnya belajar adalah merupakan kebutuhan setiap insan. Kegiatan belajar dapat dilakukan di lembaga pendidikan formal dan non formal. Lembaga pendidikan memegang peranan penting terutama dalam meningkatkan pola pikir manusia sehingga dapat cakap, kreatif dan mandiri".

Secara psikologis belajar merupakan suatu perubahan yaitu perubahan prilaku sebagai hasil dari lingkungannya Slamento (2010:2). Belajar merupakan suatu bentuk pertumbuhan atau bentuk perubahan dalam diri seseorang yang dinyatakan dalam cara tingkah laku yang baru Hamalik (2010:21). Perubahan yang terjadi mencakup perubahan tingkah laku yang mencakup perubahan pengetahuan, keterampilan dan sikap yang diperoleh siswa adalah sebagai hasil dari kegiatan belajar. Akibat yang dihasilakan dari kegiatan belajar dapat dinyatakan sebagai hasil belajar. Hasil belajar ini pada dasarnya merupakan hasil interaksi berbagai faktor yang mempengaruhi belajar secara keseluruhan.

Proses penerimaan pengetahuan baru atau penerimaan informasi kepada siswa tidak semudah yang dibayangan. Dalam proses belajar mengajar, ada beberapa faktor yang menentukan suatu pembelajaran bisa berhasil. Muhibbin (2011:5) menjelaskan faktor tersebut meliputi "faktor internal (faktor dari dalam diri siswa), faktor eksternal (faktor dari luar siswa), dan faktor pendekatan belajar (approach to learning)". Faktor internal merupakan keadaan atau kondisi jasmanai dan rohani siswa. Faktor eksternal merupakan kondisi lingkungan di sekitar siswa. Sedangkan faktor pendekatan belajar yakni jenis upaya belajar siswa yang meliputi strategi dan metode yang digunakan siswa untuk melakukan kegiatan materi-materi pembelajaran yang ada di sekolah.

Salah satu bagian yang terdapat pada faktor internal siswa yang mempengaruhi proses belajar mengajar yaitu minat. Nurkancana dan Sunartana (1999:229) mengatakan bahwa "minat sangat erat kaitannya dengan perasaan individu, objek, aktivitas, dan situasi". Sedangkan Slameto (2013:180) mendefinisikan "minat sebagai suatu rasa yang lebih suka terhadapsesuatu atau rasa ketertarikan pada suatu hal atau aktivitas". Jadi, semakin tinggi minat yang ada pada siswa dalam belajar, maka akan berbanding lurus dengan hasil pembelajarannya.

Peningkatan minat yang ada pada diri siswa bisa diupayakan dengan adanya metode yang digunakan oleh guru dalam 
pembelajaran. Slameto (2013:65) menjelaskan “proses penerimaan, penguasaan, dan pengembangan pembelajaran yang diterima oleh siswa memerlukan cara-cara mengajar dan cara belajar secara tepat, seefektif dan seefisien mungkin. Hal ini membuktikan bahwasanya metode dalam mengajar akan mempengaruhi

proses dan hasil belajar".

Metode mengajar merupakan salah satu cara yang digunakan oleh guru dalam proses belajar mengajar di sekolah agar informasi yang disampaikan oleh guru dapat diterima dengan baik oleh siswa. Salah satu bentuk metode pembelajaran yang digunakan dalam proses belajar mengajar adalah dengan belajar kelompok. Pratikno (2012: 22) menjelaskan bahwa "belajar kelompok adalah serangkaian kegiatan yang dilakukan dengan logis dan sistematis yang dilakukan oleh beberapa orang dengan memiliki kemampuan untuk berbuat dengan kesatuannya agar memperoleh perubahan tingkah laku dan belajar menjadi lebih efektif'. Belajar dalam suatu kelompok akan memberikan dampak yang signifikan kepada siswa yang berada didalam kelompok tersebut jika setiap anggota belajar secara sungguh- sungguh, berdiskusi, dan saling bekerjasama dalam menyelesaikan masalah.

Radno Harsanto (2001:65) mengatakan bahwa "Adanya belajar dalam suatu kelompok dapat meningkatkan nilai kerjasama, kekompakan, partisipasi aktif siswa, keintensifan siswa, kemampuan akademis, rasa percaya diri, dan keterampilan dasar dalam hidup". Belajar dalam suatu kelompok bisa di terapkan dalam mata pelajaran yang diajarkan di sekolah. Salah satu mata pelajaran tersebut adalahPendidikan Kewarganegaraan.

Berdasarkan urain diatas, maka peneliti terdorong untuk mengadakan penelitian dengan judul "Pengaruh Belajar Kelompok Pendidikan Kewarganegaraan (PKn) Terhadap Minat Belajar Siswa Kelas X di SMKS- PP Putra Jaya Stabat Kabupaten Langkat Tahun Pelajaran

\section{$2020 / 2021 "$.}

\section{METODELOGI PENELITIAN}

Metode penelitian ini adalah metode penelitian kuantitatif survey. Pada penelitian survei, peneliti memilih sejumlah responden sebagai sampel, dan memberikan mereka kuesioner yang sudah baku. Responden adalah orang yang memberikan data untuk dianalisis dengan cara menjawab kuesioner.

Populasi dalam penelitian ini adalah semua siswa kelas X SMKS-PP Putra Jaya Stabat Kabupaten Langkat Tahun Pelajaran 2020/2021 yang jumlah seluruhnya sebanyak 137 orang yang terdiri dari 4 kelas. Sampel yang akan diambil dalam penelitian ini adalah sebesar 34 orang siswa kelas X NAK B SMKS- PP Putra Jaya Stabat Kabupaten Langkat Tahun Pelajaran 2020/2021. Instrumen penelitian yaitu observasi, angket dan dokumentasi.

\section{HASIL \\ PEMBAHASAN}

DAN

\section{Hasil Penelitian}

Berdasarkan judul penelitian yaitu "Pengaruh Belajar Kelompok Pendidikan Kewarganegaraan (PKn) Terhadap Minat Belajar Siswa Kelas X di SMKS- PP Putra Jaya Stabat Kabupaten Langkat Tahun Pelajaran 2020/2021", maka tujuan penelitian ini adalah untuk mengetahui "pengaruh minat belajar

Pendidikan Kewarganegaraan (PKn) Siswa Setelah Diterapkan Belajar Kelompok Pada Siswa Kelas X di SMKS-PP Putra Jaya Stabat Kabupaten Langkat Tahun Pelajaran 2020/2021".

Penelitian ini dilaksanakan di SMKS-PP Putra Jaya Stabat Kabupaten Langkat Tahun Pelajaran 2020/2021. Populasi dalam penelitian ini adalah siswa kelas $\mathrm{X}$ yang berjumlah 137 siswa yang terdapat dalam 4 kelas. Sampel dalam penelitian ini adalah siswa kelas X Nak B yang berjumlah 34 siswa. 
Sebelum dilaksanakan penyebaran angket untuk menjaring minat belajar siswa setelah dilakukan pembelajaran belajar kelompok. Pelaksanaan pembelajaran yang dilakukan penelitian dilaksanakan dengan metode belajar kelompok. Setelah dilakukan belajar kelompok, kemudian peneliti menyebarkan angket untuk menjaring minat belajar siswa terhadap pelaksanaan belajar kelompok.

Angket diberikan kepada siswa yang berjumlah 34 siswa. Dari hasil sebaran angket tersebut diperoleh hasil sebagai berikut:

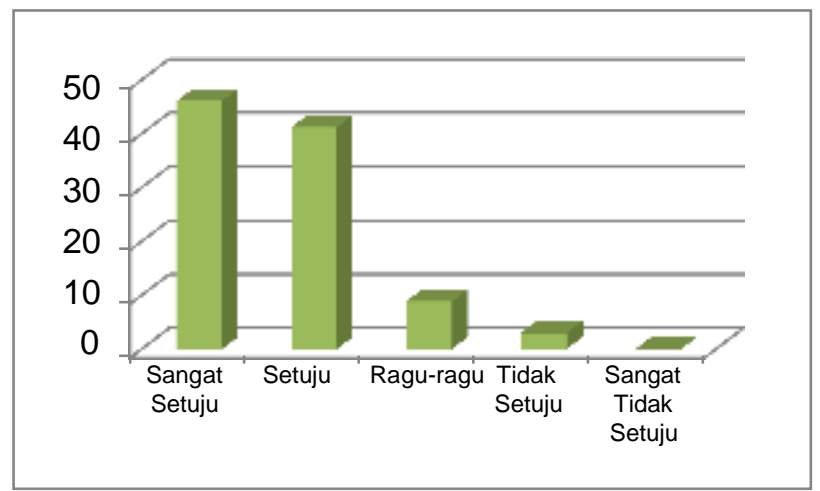

Gambar 1 Grafik Hasil Presentase Minat Belajar Siswa

Berdasarkan rata-rata pencapaian siswa mengenai minat belajar siswa yang memilih sangat setuju sebesar 46,02\% artinya siswa memiliki minat belajar yang sangat tinggi, siswa yang memilih setuju sebesar $41,17 \%$ yang artinya siswa memiliki minat belajar tinggi, sedangkan siswa yang raguragu sebesar $8,82 \%$ dan siswa yang tidak setujua sebesar $2,94 \%$ artinya siswa masih memiliki minat belajar yang rendang. Aktivitas belajar siswa dalam belajar kelompok menunjukan semangat belajar yang tinggi, siswa sangat aktif dalam belajarnya, Hasil penelitian menunjukan bahwa belajar kelompok dapat meningkatkan minat belajar siswa kelas X di SMKS-PP Putra Jaya Stabat Kabupaten Langkat Tahun Pelajaran ketertarikan siswa dalam belajar di tunjukan pada seluruh siswa ketika belajar kelompok di laksanakan. 


\section{Pembahasan Penelitian}

Dari hasil pengamatan peneliti terhadap kegiatan belajar mengajar yang peneliti lakukan menunjukan bahwa aktivitas belajar siswa dalam belajar kelompok menunjukan semangat belajar yang tinggi, siswa sangat aktif dalam belajarnya, ketertarikan siswa dalam belajar di tunjukan pada seluruh siswa ketika belajar kelompok di laksanakan.

Kegiatan belajar kelompok menunjukan kegiatan belajar yang baik. Siswa berlombalomba dalam belajarnya. Belajar kelompok memberikan kemudahan bagi siswa untuk memecahkan masalah yang dihadapi. Siswa saling memberikan masukan-masukan dalam belajar kelompok. Oleh karena itu, belajar kelompok memusahkan pemecahan masalah siswa dan membuat siswa lebih termotivasi berperan aktif dalam kelompoknya.

Penelitian dilaksanakan Oleh Nanik Puji Rahayu Fakultas Ilmu Tarbiyah Dan Keguruan, Universitas Islam Negeri Walisongo dengan judul "Efektivitas Belajar Kelompok Terhadap Hasil Belajar Materi Kenampakan Alam dan Keragaman Sosial Budaya Mata Pelajaran IPS Kelas IV Semester I MI Ianatusshibyan Semarang Tahun Ajaran 2015/2016". Tujuan penelitian ini adalah untuk mengetahui efektivitas belajar kelompok terhadap hasil belajar materi kenampakan alam dan keragaman sosial budaya mata pelajaran IPS kelas IV Semester I MI Ianatusshibyan Semarang Tahun Ajaran 2015/2016. Penelitian kuantitatif eksperimen dengan desain posttestonly control design yang dilaksanakan di kelas IV MI Ianatusshibyan Semarang tahun ajaran 2015/2016. Madrasah tersebut dijadikan sebagai sumber data untuk mendapatkan data keadaan siswa. Datanya diperoleh dengan metode dokumentasi dan tes. 32 Perbedaan dengan penelitian tersebut adalah penelitian yang penulis lakukan lebih mendalam pada pengaruh belajar kelompok teman sebaya terhadap pencapaian kompetensi dasar memahami makna keberagaman dalam bingkai bhinneka.

Penelitian dilaksanakan Oleh Fitri Atika Candra Fakultas Keguruan dan Ilmu Pendidikan Universitas Lampung Bandar lampung dengan judul "Pengaruh Belajar Kelompok Terhadap Pencapaian Kompetensi Dasar Dalam Mata Pelajaran PPKn" Tujuan dari penelitian ini yaitu untuk mendeskripsikan bagaimana pengaruh belajar kelompok terhadap pencapaian kompetensi dasar memahami makna keberagaman dalam bingkai Bhinneka Tunggal Ika mata pelajaran PPKn di kelas VIII C dan VIII E SMPN 1 Seputih Agung. Metode yang digunakan dalam penelitian ini adalah metode deskriptif dengan pendekatan kuantatif dengan populasi yang berjumlah 72 responden. Teknik pokok pengumpuan data menggunakan angket, analisis data menggunakan presentase. Hasil penelitian menunjukan bahwa belajar kelompok cukup berpengaruh dalam pencapain kompetensi dasar memahami makna keberagaman dalam bingkai Bhinneka Tunggal Ika mata pelajaran PPKn, dengan saling berbagi informasi dan menyelesaikan masalah bersama-sama dapat mempermudah siswa dalam belajar. Belajar kelompok dapat membentuk sikap siswa yang bertoleransi, menerima pendapat teman dan memiliki ketrampilan bekerjasama dalam kelompok.

\section{Temuan Penelitian}

Berdasarkan pembahasan hasil penelitian menunjukan hipotesis yang diajukan terbukti kebenarannya yaitu Terdapat Pengaruh Belajar Kelompok

Pendidikan Kewarganegaraan (PKn) Terhadap Minat Belajar Siswa Kelas X di SMKS-PP Putra Jaya Stabat Kabupaten Langkat Tahun Pelajaran 2020 /2021”.

\section{KESIMPULAN \\ DAN \\ SARAN Kesimpulan}

Berdasarkan hasil penelitian, maka 
dapat disimpulkan bahwa penelitian menunjukan hipotesis yang diajukan terbukti kebenarannya yaitu terdapat Pengaruh Belajar Kelompok Pendidikan Kewarganegaraan (PKn) Terhadap Minat Belajar Siswa Kelas X di SMKS-PP Putra Jaya Stabat Kabupaten Langkat Tahun Pelajaran 2020 /2021".

\section{A. Saran}

Berdasarkan hasil temuan penelitian ini dapat diberikan saran-saran sebagai berikut:

1. Pembelajaran dengan metode belajar kelompokdapat meningkatkan minat belajar siswa, untuk itu metode

\section{DAFTAR PUSTAKA}

Hamalik, Oemar. Belajar dan Mengajar Bandung: Remaja Rosdakarya, 2010.

Harsanto, Radno. Belajar dan Pembelajaran. Yogyakarta: Pustaka Pelajar. 2001.

Hudojo, Herman. Mengajar Belajar Matematika. Jakarta : Depdikbud. 2000.

Praktikno. Pengaruh Perhatian Orang Tua dan Intensitas Belajar Kelompok Terhadap Minat Belajar Siswa Kelas $V$ SDN Se-Gugus Cahyana Kec. Rembang Purbalingga Tahun Pelajaran 2011/2012. Yogyakarta: UNY. 2012.

Syah, Muhibbin, Psikologi Pendidikan, Bandung : Remaja Rosdakarya, 2010.

UU Sisdiknas No 20 Tahun 2003. BAB II Dasar, Fungsi dan Tujuan. pembelajaran ini dapat digunakan oleh guru sebagai alternatif dalam mengajar.

2. Bagi guru yang menggunakan model pembelajaran ini hendaknya mempersiapkan bahan atau sarana yang akan digunakan.

3. Bagi siswa-siswa agar lebih aktif dan berani dalam menyampaikan pendapat dan percaya diri dalam mengambil suatu pilihan dalam pelajaran PKn.

4. Bagi peneliti, kiranya hasil penelitian ini dapat menjadi informasi yang bergunan untuk dapat digunakan penelitan yang jenisnya sama dan sebagai bahan perbandingan. 
Wayan Nurkacana \& Sunarta. 1999. Evaluasi Pendidikan. Surabaya: Usaha Nasional.

Slameto. 2010. Belajar dan faktor-faktor yang Mempengaruhinya. Jakarta: PT. Rineka Cipta. 